\title{
Chemical characteristics of Falcataria moluccana wood infested by Boktor stem borer (Xystrocera festiva)
}

\author{
NOOR F. HANEDA ${ }^{1, \bullet}$, ASEP H. SUPRIATNA ${ }^{1}$, HASYYATI SHABRINA ${ }^{1}$, YUNIK ISTIKORINI ${ }^{1}$, \\ ULFAH J. SIREGAR ${ }^{1}$, IMAM WAHYUDI ${ }^{2}$ \\ ${ }^{1}$ Department of Silviculture, Faculty of Forestry and Environment, Institut Pertanian Bogor. J1. Ulin Lingkar Akademik, Darmaga, Bogor 16680, West \\ Java, Indonesia. Tel/fax.: +62-251-8626806, `email: nhaneda@apps.ipb.ac.id \\ ${ }^{2}$ Department of Forest Product, Faculty of Forestry and Environment, Institut Pertanian Bogor. Jl. Ulin Lingkar Akademik, Darmaga, Bogor 16680, West \\ Java, Indonesia
}

Manuscript received: 13 July 2021. Revision accepted: 16 September 2021.

\begin{abstract}
Haneda NF, Supriatna AH, Shabrina H, Istikorini Y, Siregar UJ, Wahyudi I. 2021. Chemical characteristics of Falcataria moluccana wood infested by Boktor stem borer (Xystrocera festiva). Biodiversitas 22: 4203-4208. Boktor (Xystrocera festiva Thoms.) is the most destructive and detrimental pest in Falcata plantations in Indonesia. It attacks the inner bark of sapwood when the tree reaches 3-years-old. This study aimed to analyze the chemical characteristics of Falcata woods, which were infested with Boktor in trees aged 3 and 4 years, compared to the healthy tree at 2 years old. The primary chemical components and type of extractive compounds were analyzed using standard procedures. The results showed a decrease in hemicellulose and an increase in lignin content of infected wood. This condition occurs because Boktor larvae prefer hemicellulose rather than lignin, which is related to the presence of enzymes in the digestive system of the larvae. The decreasing extractive contents as trees grow and undergo age-related shifting metabolism can be alleged as the start of Boktor infestation in 3-years-old trees. Boktor infestation also altering the wood chemical components by degrading the lignin that produced 4-vinyl-syringol. The isoeugenol compound is thought to prevent Boktor infestation in the early period of tree growth.
\end{abstract}

Keywords: Boktor (Xystrocera festiva), chemical characteristics, pyrolysis analysis, Falcata (Falcataria moluccana)

\section{INTRODUCTION}

The Boktor stem-borer (Xystrocera festiva Thoms.) is the most detrimental pest in Falcata (Falcataria moluccana) plantations in Indonesia. This pest destroys the inner bark and sapwood and usually starts the attack when the tree has reached three years old. In Java Island, this pest is also known as Boktor, Uter-Uter, Wowolan, Serendang beetle or Engkes-Engkes. This pest could cause the death of trees, broken stems and reduces the productivity and quality of the wood produced. The financial losses resulting from this pest infestation ranged from $3.8 \%$ per ha in 4-years-old Falcata stands to $10.6 \%$ per ha in 8 years stands (Husaeni 2010).

The infestation begins with the laying of about 400 eggs in groups (Duladi 2012) under the bark through the wounded or damaged part of the stem, young larvae instantly damage the interior of the bark and outside of the sapwood once the eggs hatch (Haneda et al. 2020) and visible when the tree reaches three years of age. The larvae feed on the inner bark, cambium, and sapwood. The feeding direction of the larvae starts from the top towards the bottom of the stem (Darwiati and Anggraeni 2018). The further down the stem, the more extensive the damage because the more significant the larvae size would become.

Although the wood xylem has been produced before the tree reaches 1-year-old, it is still a question as to why the infestation only start at a 3-years-old tree, even though the anatomical structures of Falcata wood at the age of 1 to 6 years does not differ at all, dominated by juvenile wood (Rahayu et al. 2013).

With the except for genetic characterization of highly infested and healthy Falcata trees (Siregar et al. 2019) and the presence of Boktor digestive enzymes inhibitors (Siregar et al. 2020), information about internal host factors that influencing Boktor infestation is still limited. Therefore, this research aimed to analyze the characteristics of chemical components on Falcata woods aged 2, 3, and 4 years to determine which chemical components contribute to Boktor infestation.

\section{MATERIALS AND METHODS}

\section{Sample preparation}

The trees from a permanent plot in RPH Pandantoyo, BKPH Pare, KPH Kediri, Perhutani Unit II, East Java Province were used in this study. Wood samples were taken from the trees at three ages, namely 2-, 3- and 4years-old. The 2-years-old tree was healthy, non-infested (free-wound), while the 3- and 4-years-old ones were the most severely damaged by Boktor larvae. After cutting the trees, the wood part containing the wound (from 3- and 4years-old trees) and unwounded wood (from 2-years-old trees) were separated and then macerated into wood powder 40-60 mesh. Thus, the number of samples used for chemical components measurement from each tree was three. The size was conducted in Duplo. 


\section{Holocellulose content measurement}

A sodium chlorite procedure followed the Holocellulose analysis following the Chinese national standard GBT2677.10-1995. Two grams of wood powder (40-60 mesh) were placed in an Erlenmeyer flask and then filled with $100 \mathrm{ml}$ Aquades, $1 \mathrm{~g}$ sodium chloride, and $1 \mathrm{ml}$ acetic acid glacial. The samples were then heated using a water bath at $80^{\circ} \mathrm{C}$ for 1 hour with the water bath water surface consistently higher than the sample surface. We added $1 \mathrm{~g}$ sodium chlorite and $0.2 \mathrm{ml}$ acetic acid every 15 minutes. The samples were then filtered using a glass filter and washed with hot water. Next, a $25 \mathrm{ml} \mathrm{10 \%} \mathrm{acetic} \mathrm{acid}$ was added to the sample briefly before samples were rinsed again in hot water until acid-free. Samples were then heated in the oven at $105 \pm 3^{\circ} \mathrm{C}$ until constant weight, then cooled down and weighed. Holocellulose content was calculated using the following formula:

Holocellulose content $(\%)=\frac{\text { Hollocellulose weight }}{\text { Dried powder weight }} \times 100$

\section{$\alpha$-cellulose and hemicellulose contents measurement}

$\alpha$-cellulose were determined following the Technical Association of Pulp and Paper Industry (TAPPI T-203). A $1.5 \mathrm{~g}$ Holocellulose sample was put into a $200 \mathrm{ml}$ flask and then filled with $75 \mathrm{ml} 17.5 \% \mathrm{NaOH}$ and incubated at room temperature for 30 minutes. $100 \mathrm{ml}$ of Aquades, then added and left at room temperature for the next 30 minutes. The solution was then filtered using a filter plate and rinsed with water and $10 \%$ acetic acid 3 times. The filtered materials were washed until acid-free. The samples were heated in the oven at $105 \pm 3^{\circ} \mathrm{C}$ until constant weight. The $\alpha$-cellulose content was calculated using the following formula:

$$
\alpha \text {-cellulose content }(\%)=\frac{\alpha \text {-cellulose weight }}{\text { Dried powder weight }} \times 100
$$

Hemicellulose content was determined as the difference between Holocellulose and $\alpha$-cellulose content.

\section{Extractive content measurement and its compound analysis}

The solubility of wood in ethanol-benzene $(1: 2, \mathrm{v} / \mathrm{v})$, cold and hot water as well as in $1 \% \mathrm{NaOH}$ was measured following The Technical Association of Pulp and Paper Industry (TAPPI T-207 and TAPPI T-212) and American Society for Testing and Material (ASTM D 1107-96), respectively. To identify their compounds, the infested and non-infested wood powders were analyzed with Gas Chromatography-Mass Spectrometry (GCMS) using Agilent 6890 as the medium and HP 5975 mass selective detector.

\section{Data analysis}

The data was then analyzed descriptively, presented in graphs and tables. Finally, a comparison of what was found in the infested and non-infested wood was made to know the difference between those two samples and relate the differences with the Boktor pest preference to the part and age of the Falcata tree infestation.

\section{RESULTS AND DISCUSSION}

\section{Results}

The insects need cellulose, starch, hemicellulose, and protein to live. Therefore, the chemical components of woods were analyzed to gain insight into the effect of wood components on the insect. The average value of the primary chemical component of Falcata wood in each age is presented in Table 1. It can be seen that hemicellulose content tends to decrease with the increasing age of the tree, while $\alpha$-cellulose and lignin contents tend to increase.

Compared to Haneda et al. (2020), the average value of the $\alpha$-cellulose content from this study was lower, while Holocellulose and hemicellulose contents were almost similar. According to them, $\alpha$-cellulose content for hardwood species was $40-45 \%$, while hemicellulose and lignin were $15-35 \%$ and $17-25 \%$, respectively.

In general, the chemical components of wood consist of primary and secondary components. The primary component, namely Holocellulose, consists of cellulose and hemicellulose as well as lignin. The secondary component consists of extractives and other inorganic materials. Figure 1 shows the overall chemical components of 2-, 3- and 4year-old Falcata wood, while Figure 2 shows their differences between the lower and upper parts of the stem. It can be seen that Holocellulose tends to decrease with the increasing age of the tree, while the lignin tends to increase. The extractives show different tendencies and fluctuations. They decrease from 2- to 3-year-old but then increase from 3 to 4-year-old (Figure 1).

Figure 2 shows significant effects of sample location on chemical components, except for Holocellulose at a 3-yearold and 4-year-old tree and lignin content at a 3-year-old tree. In the cases of lignin content of 2-year-old and extractive content of 3-year-old, our findings are not in agreement because they tended to decrease from the bottom towards the top. According to Cabalová et al. (2021), the extractive content of both wood and bark increases vertically from the base toward to top part of the tree. On the other hand, Roitto et al. (2016) found that the extractive content in birch stem wood rises from the bottom toward the top. These discrepancies are probably due to random samplings.

The solubility of wood in ethanol-benzene $(1: 2, \mathrm{v} / \mathrm{v})$, cold and hot water, as well as in $1 \% \mathrm{NaOH}$ are presented in Figure 3. It can be seen that extractive content varies and depends on tree age and the solvent. For example, Lipophilic extracts (terpenoids and aliphatics) are more soluble in less polar solvents, whereas hydrophilic extracts (phenolics) are more soluble in more polar solvents (Routa et al. 2017). Extractives are non-structural chemicals with a low molecular mass that are found in wood. Resins, terpenes, alkaloids, lipid, gums, waxes, proteins, phenolics, pectins, and essential oils are among them (Nascimento et al. 2013). The majority of the extractives are secondary metabolites, which are substances that have a purpose other than growth and cell development in a tree, such as protecting the tree from infections or other biotic attacks (Metsämuuronen and Sirén 2019). 
Table 1. The primary chemical components on 2-, 3- and 4-yearold Falcata wood

\begin{tabular}{ccccc}
\hline \multirow{2}{*}{$\begin{array}{c}\text { Age } \\
\text { (year) }\end{array}$} & Holocellulose & $\begin{array}{c}\boldsymbol{\alpha} \text { - } \\
\text { cellulose }\end{array}$ & Hemicellulose & Lignin \\
\cline { 2 - 5 } & 67.92 & 30.92 & 37.00 & 24.52 \\
3 & 66.57 & 31.77 & 34.80 & 26.57 \\
4 & 66.11 & 33.57 & 32.54 & 26.82 \\
\hline
\end{tabular}
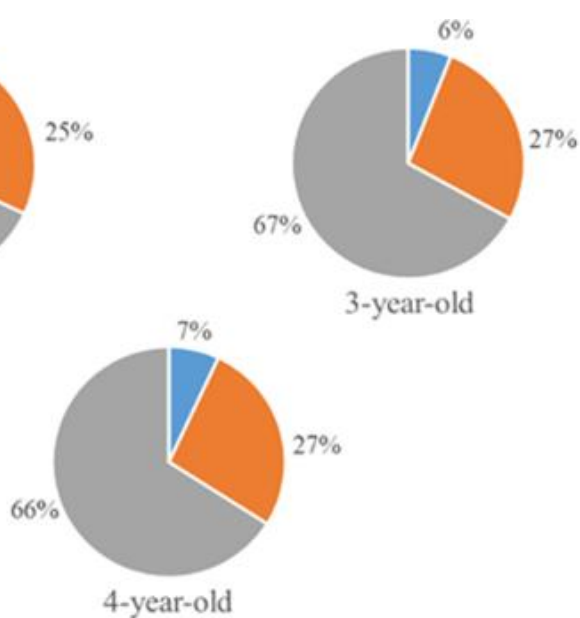

n extractive compound = lignin $=$ holocellulose

Figure 1. Chemical component differences in 2-, 3- and 4-yearold Falcata wood

To determine the extractive compounds of Falcata, pyrolysis analysis was carried out using a GC-MS. The chromatograms show that there are different peaks in each age (Figure 4). For example, there are five peaks in 2- and 4-year-old wood, while there are only four peaks, while in 3 -year-old wood, only four peaks. Furthermore, the peak is correlated to the chemical compounds of the extractive (Table 2).
Table 2. Chemical compounds found in the extractives of Falcata wood

\begin{tabular}{ccccccccc}
\hline Age & \multicolumn{8}{c}{ Chemical compounds existed in the extractives } \\
\cline { 2 - 8 } (year) & $\mathbf{1}$ & $\mathbf{2}$ & $\mathbf{3}$ & $\mathbf{4}$ & $\mathbf{5}$ & $\mathbf{6}$ & $\mathbf{7}$ \\
\hline 2 & $\sqrt{ }$ & $\sqrt{ }$ & $\sqrt{ }$ & $\sqrt{ }$ & $\sqrt{ }$ & - & - \\
3 & - & - & $\sqrt{ }$ & $\sqrt{ }$ & $\sqrt{ }$ & $\sqrt{ }$ & - \\
4 & $\sqrt{ }$ & - & $\sqrt{ }$ & $\sqrt{ }$ & $\sqrt{ }$ & - & $\sqrt{ }$ \\
\hline Note: 1: & phenol-2-methoxy-4-(1-propenyl)-; & $2:$ & $4,11-d i o x a-3,5-$ \\
dimethyltetracycloundecane; & $3:$ & phenol-2,6-dimethoxy-4-(2-propeny
\end{tabular}
1)-; 4: 4-((1E)-3-hydroxy-1-propenyl)-2-methoxyphenol; 5: syringyl acetone; 6: 4-vinyl-syringol; dan 7: 1,4-dihydrophenanthrene

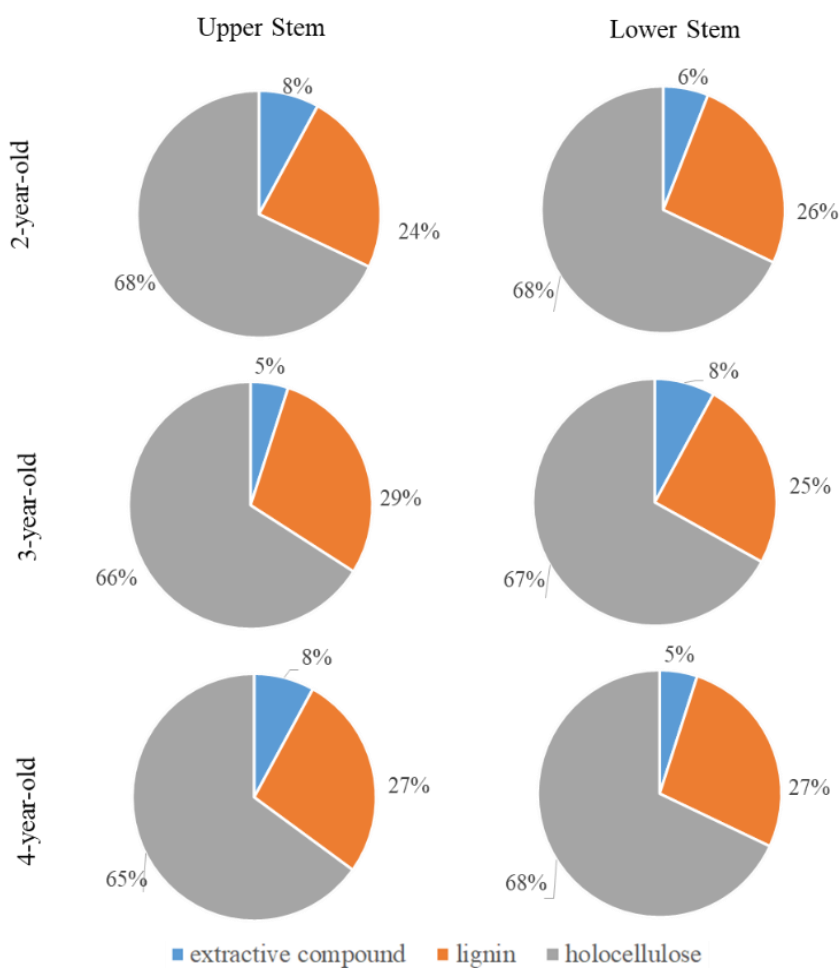

Figure 2. Chemical component differences between the upper and lower part of Falcata stem

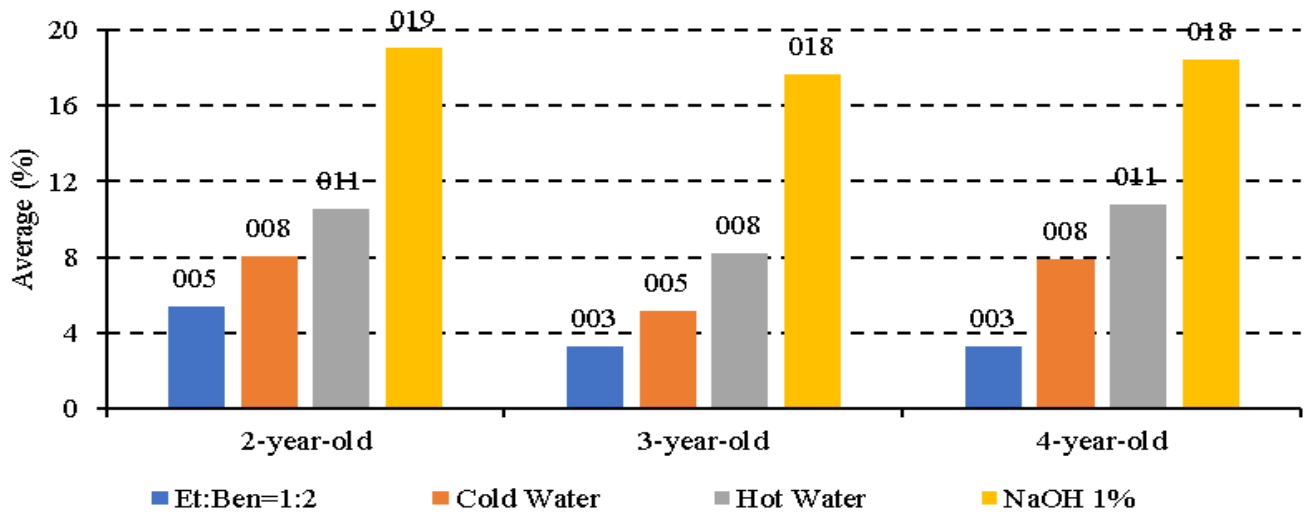

Figure 3. Extractive content of Falcata wood in various solvents 

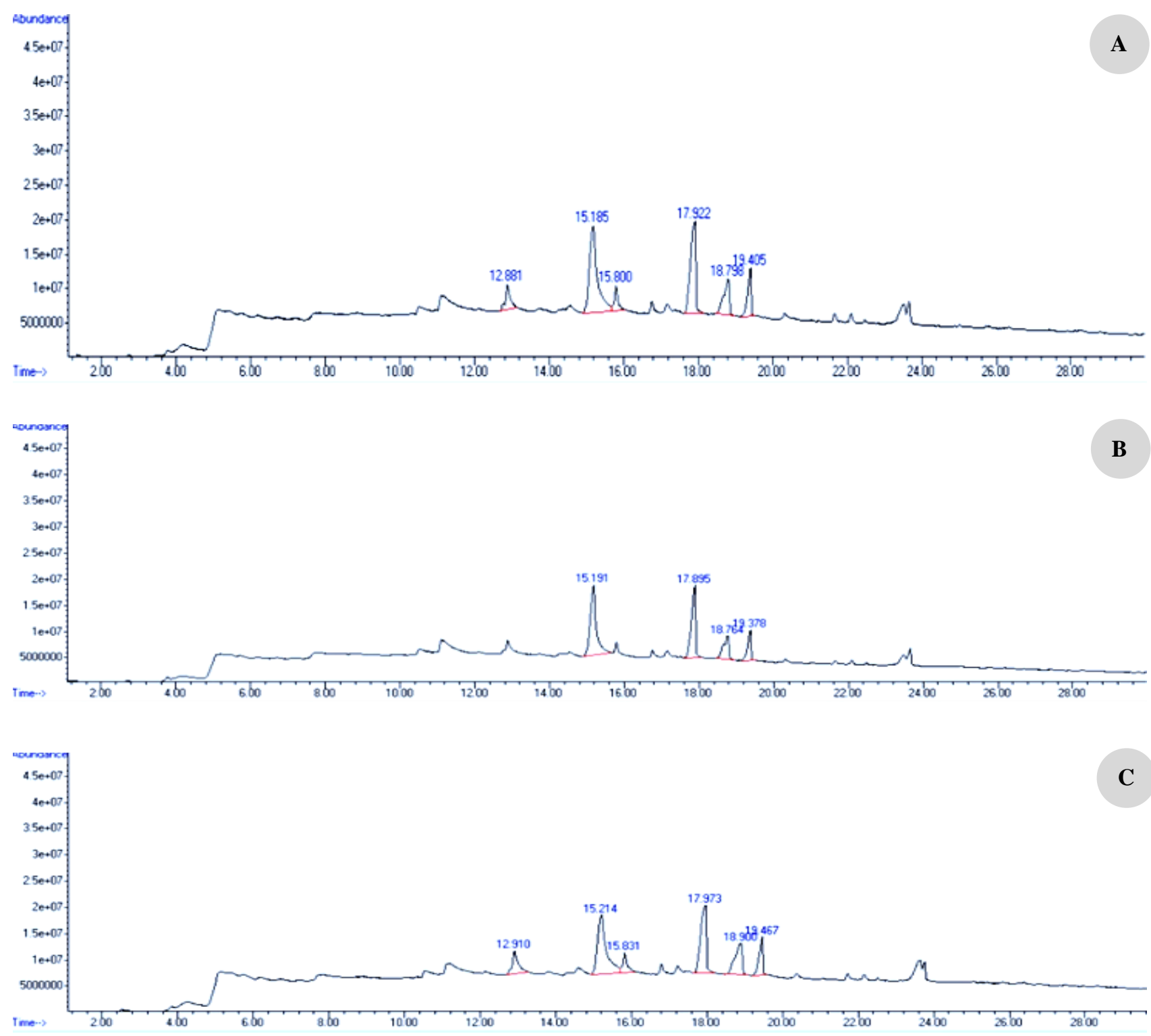

Figure 4. GC-MS chromatograms of Falcata wood from 2 (A), 3 (B), and 4-years-old (C) trees

The checkpoints in the table indicate peaks present in the chromatograms of the samples. In those chromatograms, two peaks showed as dominant compounds, with 15.18 and 17.9 of retention time. These two compounds were phenol-2,6-dimethoxy-4-(2-propenyl) and 4-((1E)-3-hydroxy-1-propenyl)-2-methoxyphenol both of these compounds classified into phenolic compounds.

\section{Discussion}

According to Haneda et al. (2020), Boktor larvae eat carbohydrates generated from hemicellulose, cellulose, and starch. In Table 1, we can see a decrease in hemicellulose content in the infested wood (3- and 4-years-old trees) compared to that in non-infested wood (2-years-old tree) inversely proportional to the high lignin contents. These confirm that Boktor larvae prefer hemicellulose to lignin or cellulose because it has trypsin and $\alpha$-amylase that can degrade protein and hemicellulose (Siregar et al. 2020).
Hemicellulose is a general term for a group of polysaccharides that are different from cellulose because this fraction is amorphous and easily soluble or hydrolyzed in alkaline or acidic solutions (Santiago et al. 2013).

Meanwhile, lignin is a polyphenol that has a threedimensional structure and many branches. In addition, lignin has a complex molecular structure with a high molecular weight making it more difficult for insects to digest because insects lack ligninases (Douglas 2013).

According to Donaldson et al. (2006); Morais and Pereira (2012); Miranda et al. (2017), the food for Boktor larvae mostly comes from the sapwood because the cells that make up the sapwood are still alive and contain a lot of water, so it is easier to digest, while their lignin and extractive contents are less. Therefore, these extractive compounds impact insect colonization in tree trunks (Mounguengui et al. 2016). 
Boktor started infesting Falcata stands at the age of 3 years. This phenomenon was reinforced and well confirmed by a decrease in the extractive content of infected wood ( 3 years) compared to 2 years of age (Figure 1 and 3). In all treatments, the extractive content in 3 -yearold timber decreased, except for the treatment using ethanol-benzene. From these results, it can be assumed that the decrease in extractive content causes Boktor infestation, or in other words, it is easier for Boktor to attack the 3years-old stands.

Plants have developed a variety of methods to accommodate changes in their changing growth circumstances, allowing them to function more freely under the influence of external conditions without damaging their cellular and developmental, physiological processes through the production of a diverse range of secondary metabolites (Yang et al. 2018; Arnold et al. 2019). The species, genotype, physiology, developmental stage, and environmental variables influence the kind and quantities of secondary metabolites generated by a plant throughout growth. This finding implies that many plant taxonomic groupings use physiological adaptation responses to cope with stress and defensive stimuli (Isah 2019). A study by Bielecka and Matkowski (2019) using Agastache rugosa found that the polyphenols content produced vary over time. This condition also occurs in trees that grow naturally in boreal forests, of which their secondary metabolic composition changed over time (Wam et al. 2017).

Result of GC-MS pyrolysis analysis shows that there are 7 main compounds that make up Falcata wood extractive substances, i.e. phenol-2-methoxy-4-(1propenyl); 4,11-dioxa-3,5-dimethyltetracycloundecane; phenol-2,6-dimethoxy-4- (2-propenyl); 4-((1E)-3-hydroxy1-propenyl)-2-methoxyphenol; syringyl acetone; 4-vinylsyringol and 1,4-dihydrophenanthrene (Table 2). The compound number 7 is phenanthrene phytoalexin, number 2 is undecane, while numbers $1,3,4,5$, and 6 can be classified into phenolic compounds. Phenolic compounds are found in all plant parts, i.e., flowers, fruits, seeds, leaves, roots, bark, and lignified parts (SzwajkowskaMichałek et al. 2020). They could be an essential element of the plant defense mechanism against pests and disease (Pagare et al. 2015; Kovalikova et al. 2019). Syringyl acetone, one of the phenolic derivates compounds, was found and isolated in syringaresinol. Syringaresinol is a lignan precursor that plays an essential role in plant defense against diseases. It has also been proposed that lignans might function as insect antifeedants by affecting the insect endocrine system (Paniagua et al. 2017). Undecane belongs to the class of organic compounds known as alkanes. This compound in bananas dominated the development of female flowers (Masriany et al. 2017). Phenanthrene can be used for pesticides manufacturing (Abdel-Shafy and Mansour 2016). Phytoalexins are, in general, insectinduced defense compounds and act in preventing insecteating (Yactayo-Chang et al. 2020).

Phenol-2-methoxy-4-(1-propenyl) or isoeugenol (synonym) was not found in the 3-years-old or infested wood only (Table 2). The undetectable isoeugenol in 3years-old wood indicated a decrease in the metabolism of this compound at that age. Isoeugenol is a phenylpropene that is one of the most significant components of natural flavors and is known to have antioxidant and antibacterial properties (Yang et al. 2021). However, as an insecticide, it also has moderate toxicity to red palm weevil (Rhynchophorus ferrugineus) (AlJabr et al. 2017).

On the contrary, 4-vinyl-syringol is a compound that is only found in 3-years-old or infested wood. Its function in the plant itself is still rarely known. 4-vinylsyringol is one of the compounds found in artificial feed using Birch (Betula sp.) wood which termites can digest. The compound is also found in the digestive system of termites (Miambi et al. 2020). Vinylsyringol itself resulted from lignin degradation by fungi from Trichoderma genera (Bohacz and Kornillowicz-Kowalska 2020). As a result, the Boktor infestation probably triggered the production of 4-vinylsyringol. The changing metabolism after pest infestation was also observed in Kovalikova et al. (2019) study in white cabbage.

In conclusion, the studies show that the Boktor pest, especially the larvae, preferred hemicellulose to other chemical components. As trees get older, the hemicellulose content was found to decrease, while the lignin content increased. The decrement in extractive contents of Falcata wood was suspected of triggering Boktor infestation on 3years-old Falcata stands. According to the results of the pyrolysis test, the absence of isoeugenol was suspected as a marker of Boktor infestation during the early growth stage.

\section{ACKNOWLEDGEMENTS}

The authors would like to thank RPH Pandantoyo, BKPH Pare, KPH Kediri, Perhutani Unit II, East Java for samples of Falcata trees; to Wood Chemistry Laboratory, Department of Forest Product, Faculty of Forestry and Environment, IPB University, Bogor, Indonesia for wood chemical analysis; and to POLRI Forensic Center Laboratory, South Jakarta for analysis of the chemical content of wood extractive substances.

\section{REFERENCES}

Abdel-Shafy HI, Mansour MSM. 2016. A review on polycyclic aromatic hydrocarbons: Source, environmental impact, effect on human health and remediation. Egypt $\mathrm{J}$ Pet 25(1): 107-123. DOI: 10.1016/j.ejpe.2015.03.011.

AlJabr AM, Hussain A, Haq MR, Al-Ayeds HY. 2017. Toxicity of plant secondary metabolites modulating detoxification genes expression for natural red palm weevil pesticide development. Molecules 22(1): 169. DOI: 10.3390/molecules22010169.

Arnold PA, Kruuk LE, Nicotra AB. 2019. How to analyze plant phenotypic plasticity in response to a changing climate. New Phytol 222(3): 1235-1241. DOI: 10.1111/nph.15656.

Bielecka M, Matkowski A. 2019. Age-related variation of polyphenol content and expression of phenylpropanoid biosynthetic genes in Agastache rugosa. Ind Crops Prod 141: 111743. DOI: 10.1016/j.indcrop.2019.111743.

Bohacz J, Kornillowicz-Kowalska T. 2020. Modification of postindustrial lignin by fungal strains of the genus Trichoderma isolated from different composting stages. J Environ Manag 266: 110573. DOI: 10.1016/j.jenvman.2020.110573. 
Cabalová I, Bélik M, Kucerová V, Jurczyková T. 2021. Chemical and morphological composition of Norway Spruce Wood (Picea abies, L.) in the dependence of its storage. Polymers 13: 1619. DOI: 10.3390/polym13101619.

Darwiati W, Anggraeni I. 2018. The Boktor and tumor attack at Sengon in the plantation of Tea Ciater. Jurnal Sains Natural 8(2): 59-69. DOI: 10.31938/jsn.v8i2.119. [Indonesian]

Donaldson JR, Stevens MT, Barnhill HR, Lindroth RL. 2006. Age-related shifts in leaf chemistry of clonal aspen (Populus tremuloides). NLM 32: 1415-1429. DOI: 10.1007/s10886-006-9059-2.

Douglas AE. 2013. Microbial brokers of insect-plant interactions revisited. J Chem Ecol 39: 952-961. DOI: 10.1007/s10886-013-0308-

Duladi. 2012. Smart Way to Control Pests and Diseases on Sengon. PT IPB Press, Bogor. [Indonesian]

Haneda NF, Ichtisinii A,Siregar UJ, Istikorini Y, Lestari A. 2020 Chemical component of Sengon tree digested Xystrocera festiva (Coleoptera: Cerambycidae) larvae. Advances in Biological Sciences Research; Proceedings of the 3rd KOBI Congress, International and National Conferences (KOBICINC 2020). DOI: 10.2991/absr.k.210621.049.

Husaeni EA. 2010. Xystrocera festiva Thoms (Cerambycidae: Coleoptera): Biology and Control in Sengon Plantation Forest. IPB Press, Bogor. [Indonesian]

Isah T. 2019. Stress and defence responses in plant secondary metabolites production. Biol Res 52: 39. DOI: 10.1186/s40659-019-0246-3.

Kovalikova Z, Kubes J, Skalicky M, Kuchtickova N, Maskova L, Tuma J, Vachova P, Hejnak V. 2019. Changes in content of polyphenols and ascorbic acid in leaves of white cabbage after pest infestation. MDPI 24914: 2622. DOI: 10.3390/molecules24142622.

Masriany M, Esyanti RR, Dwivany FM, Anggraeni T. 2017. Banana flower-insect interaction: Alpha-Pinene as potential attractant for the insect vector of banana blood disease. Hayati J Biosci 27(1): 8-15. DOI: $10.4308 / \mathrm{hjb} .27 .1 .8$.

Metsämuuronen S, Sirén H. 2019. Bioactive phenolic compounds, metabolism, and properties: A review on valuable chemical compounds in Scots pine and Norway spruce. Phytochem Rev 18: 623-664. DOI: 10.1007/s11101-019-09630-2.

Miambi E, Jusselme MD, Cézard L, Pion F, Baumberger S, Robert A, Lapierre C, Diouf M, Mora P. 2020. A technical soda lignin as sole carbon-diet for a higher termite species, nasutitermes ephratae: Insight into the changes in the gut bacterial community and in the lignin phenolic fraction. Research Square. DOI: 10.21203/rs.3.rs28014/v1.

Miranda I, Sousa V, Ferreira J, pereira H. 2017. Chemical characterization and extractives composition of heartwood and sapwood from Quercus faginea. PloS ONE 12(6): e0179268. DOI: 10.1371/journal.pone.0179268.

Morais MSM, Pereira H. 2012. Variation of extractives content in heartwood and sapwood of Eucalyptus globulus trees. Wood Sc Technol 46: 709-719. DOI: 10.1007/s00226-011-0438-7.

Mounguengui S, Saha Tchinda JB, Ndikontar MK et al. 2016. Total phenolic and lignin contents, phytochemical screening, antioxidan and fungal inhibition properties of the heartwood extractives of ten
Congo Basin tree species. Ann For Sci 73: 287-296. DOI: 10.1007/s13595-015-0514-5.

Nascimento MS, Santana AL, Maranhao CA, Oliveira LS, Bieber L. 2013. Phenolic extractives and natural resistance of wood. In: Biodegradation - Life of Science. In Tech. DOI: 10.5772/56358

Pagare S, Bhatia M, Tripathi N, Pagare S, Bansal YK. 2015. Secondary metabolites of plants and their role: Overview. Curr Trends Biotechnol Pharm 9(3):293-304

Paniagua C, Bilkova A, Jackson P, Dabravolski S, Riber W, Didi V, Houser J et al. 2017. Dirigent proteins in plants: Modulating cell wall metabolism during abiotic and biotic stress exposure. J Exp Bot 68 (13): 3287-3301. DOI: 10.1093/jxb/erx141.

Rahayu I, Darmawan W, Nugroho N, Nandika D, Marchal R. 2013. Demarcation point between juvenile and mature wood in Sengon (Falcataria moluccana) and Jabon (Anthocephalus cadamba). J Trop For Sci 26(3): 331-339.

Roitto M, Siwale W, Tanner J, Ilvesniemi H, Julkunen-Tiitto R, Verkasalo E. 2016. Characterization of extractives in tree biomass and byproducts of plywood and sawmills from Finnish birch in different climatic regions for value-added chemical products. 5th International Scientific Conference on Hardwood Processing 2015; International Academy of Wood Science - Annual Meeting. Quebec City, Canada, 15-17 September 2015

Routa J, Brännström H, Anttila P, Mäkinen M, Jänis J, Asikainen A. 2017. Wood extractives of Finnish pine, spruce, and birch - availability and optimal sources of compounds: A literature review. Natural Resources Institute Finland (Luke), Helsinki.

Santiago R, Barros-Rios J, Malvar RA. 2013. Impact of cell wall composition on maize resistance to pests and diseases. Int J Mol Sci 14(4): 6960-6980. DOI: 10.3390/ijms14046960.

Siregar UJ, Rahmawati D, Damayanti A. 2019. Fingerprinting Sengon (Falcataria moluccana) accessions resistant to Boktor pest and gallrust disease using microsatellite markers. Biodiversitas 20(9): 26982706. DOI: 10.13057/biodiv/d200935.

Siregar UJ, Situmorang IM, Pasaribu FA, Lestari A, Istikorini Y, Haneda NF. 2020. Trypsin inhibitor activities as defense mechanism of Sengon (Falcataria moluccana) against pest attacks. IOP Conf Ser Mater Sci Eng 935(1): 012034. DOI: 10.1088/1757899x/935/1/012034.

Szwajkowska-Michałek L, Przybylska-Balcerek A, Rogozinski T, StuperSzablewska K. 2020. Phenolic compounds in trees and shrubs of Central Europe. Appl Sci 10: 6907. DOI:10.3390/app10196907.

Wam HK, Stolter C, Nybakken. 2017. Compositional changes in foliage phenolics with plant age, a natural experiment in boreal forests. J Chem Ecol 43: 920-928. DOI: 10.1007/s10886-017-0881-5.

Yactayo-Chang JP, Tang HV, Mendoza J, Christensen SA, Block AK. 2020. Plant defence chemicals against insect pests. Agronomy 10: 1156. DOI: $10.3390 /$ agronomy10081156.

Yang L, Wen KS, Ruan X, Zhao YX, Wei F, Wang Q. 2018. Response of plant secondary metabolites to environmental factors. Molecules 23(4): E762. DOI: 10.3390/molecules23040762.

Yang D, Seo K, Kang H. 2021. Alignment layer of liquid crystal using plant-based isoeugenol-substituted polystyrene. Polymers 13(547): 112. DOI: $10.3390 /$ polym 13040547. 